Article

\title{
The HMGB1/RAGE Pro-Inflammatory Axis in the Human Placenta: Modulating Effect of Low Molecular Weight Heparin
}

\author{
Cristian Zenerino ${ }^{1,+}{ }^{\dagger}$ Anna Maria Nuzzo ${ }^{1,+}$ () , Domenica Giuffrida ${ }^{1}$, Marilisa Biolcati ${ }^{1}$, \\ Alessandra Zicari ${ }^{2}$, Tullia Todros ${ }^{1}$ and Alessandro Rolfo ${ }^{1, *}$ (iD \\ 1 Department of Surgical Sciences, University of Turin, 10126 Turin, Italy; \\ cristian.zenerino@gmail.com (C.Z.); a.nuzzo@unito.it (A.M.N.); dgiuffrida@inwind.it (D.G.); \\ marilisa.biolcati@unito.it (M.B.); tullia.todros@unito.it (T.T.) \\ 2 Department of Experimental Medicine, Sapienza University of Rome, 00185 Rome, Italy; \\ alessandra.zicari@uniroma1.it \\ * Correspondence: alessandro.rolfo@unito.it; Tel.: +39-011-3134433 \\ + These authors contributed equally to this work.
}

Received: 9 October 2017; Accepted: 14 November 2017; Published: 17 November 2017

\begin{abstract}
We evaluated whether physiological and pre-eclamptic (PE) placentae, characterized by exacerbated inflammation, presented alterations in pro-inflammatory High Mobility Group Box 1 (HMGB1) and its Receptor of Advanced Glycation End products (RAGE) expression. Moreover, we investigated, in physiological placental tissue, the ability of Low Molecular Weight Heparin (LMWH) to modify HMGB1 structural conformation thus inhibiting RAGE binding and HMGB1/RAGE axis inflammatory activity. HMGB1, RAGE, IL-6 and TNF $\alpha$ (HMGB1/RAGE targets) mRNA expression were assessed by Real Time PCR. HMGB1, RAGE protein levels were assessed by western blot assay. Physiological term placental explants were treated by $0.5 \mathrm{U}$ LMWH for 24 or $48 \mathrm{~h}$. HMGB1 and RAGE expression and association were evaluated in LMWH explants by RAGE immunoprecipitation followed by HMGB1 immunoblot. HMGB1 spatial localization was evaluated by immuofluorescent staining (IF). HMGB1 expression was increased in PE relative to physiological placentae while RAGE was unvaried. $24 \mathrm{~h}$ LMWH treatment significantly up-regulated HMGB1 expression but inhibited HMGB1/RAGE complex formation in physiological explants. RAGE expression decreased in treated relative to untreated explants at $48 \mathrm{~h}$. IF showed HMGB1 localization in both cytoplasm and nucleus of mesenchymal and endothelial cells but not in the trophoblast. IL- 6 and TNF $\alpha$ gene expression were significantly increased at $24 \mathrm{~h}$ relative to controls, while they were significantly down-regulated in $48 \mathrm{~h}$ vs. $24 \mathrm{~h}$ LMWH explants. Our data depicted a new molecular mechanism through which LMWH exerts its anti-inflammatory effect on PE placentae, underlying the importance of HMGB1/RAGE axis in PE inflammatory response.
\end{abstract}

Keywords: heparin; HMGB1; placenta; pre-eclampsia; receptor for advanced glycation end products (RAGE)

\section{Introduction}

Pre-eclampsia (PE) is a severe placenta-related syndrome that affects $5-8 \%$ of all pregnancies, representing one of the main causes of fetal-maternal morbidity and mortality in developed countries [1]. PE is characterized by severe maternal hypertension, proteinuria and exacerbated systemic and placental inflammation [2]. The syndrome becomes evident only after the 20th weeks of gestation but it likely originates during first trimester of pregnancy when the trophoblast invades the maternal decidua causing spiral artery remodeling [1]. In PE, trophoblast invasion is impaired, 
leading to aberrant placental perfusion, oxidative stress and consequent inflammation and endothelial dysfunction $[3,4]$. This pathologic environment further promotes the release of pro-inflammatory cytokines and syncithiotrophoblast debris into the maternal circulation, directly activating the endothelium thus causing systemic inflammation $[4,5]$.

Among many players of the PE inflammatory response, there is increasing interest in a group of proteins known as Damage Associated Molecular Patterns (DAMPs) that work as an endogenous danger signal [6,7]. DAMPs have been highlighted as key inflammation activators during PE, preterm labor and pregnancy-related metabolic dysfunction [7]. The High Mobility Group Box 1 (HMGB1) is considered the "prototype" of DAMPs. Discovered 40 years ago as non-histone chromatin associated protein [8], HMGB1 is directly released from activated monocytes and macrophages or passively discharged by damaged/necrotic cells to induce inflammatory cytokines production [9,10], immune cells maturation and tissues remodeling [11,12]. The main mediator of HMGB1 inflammatory activity is the Receptor of Advanced Glycation End products (RAGE) [13]. After HMGB1 binding, RAGE activates the Nuclear Factor kappa B (NF-kB) pathway which induces the production of pro-inflammatory cytokines as Interleukin 6 (IL-6) and Tumor Necrosis Factor $\alpha$ (TNF- $\alpha$ ) [14]. IL-6 is pivotal for the acute phase response [15] while TNF $\alpha$, beside its typical immunomodulatory activities, inhibits first trimester extravillous trophoblast invasion by triggering apoptosis and decreasing cytotrophoblast proliferation $[16,17]$. Importantly, IL-6 $[18,19]$ and TNF $\alpha$ over-expression were reported in the placental tissue and maternal serum of PE women $[16,19,20]$.

HMGB1 involvement in inflammatory diseases has been widely demonstrated and the administration of anti-HMGB1 antibodies resulted in decreased organ damage and mortality in several models of exacerbated inflammation [15-19]. In PE pathogenesis and placental inflammation, the HMGB1/RAGE role is controversial. In PE placentae, HMGB1 was found increased [20,21] while RAGE expression was reported either significantly higher [22] or unchanged [20].

Despite intensive investigation on PE pathogenesis, no effective therapy is currently available except for a timed and often pre-term delivery. This intervention can resolve maternal symptoms but it could be extremely dangerous for the fetus, causing also severe long-term sequelae. Low Molecular Weight Heparin (LMWH), a renowned anti-coagulant, has been recently investigated as a therapeutic approach for preeclampsia and other pregnancy-related complications. The anticoagulant therapy was first proposed for pregnant women with thrombophilia, characterized by utero-placental thrombosis and poor obstetric outcomes [23]. The use of anticoagulants during pregnancy was suggested more than 40 years ago for women which underwent previous placental infarction [24]. The rationale was that a better placental function might be obtained by reducing the risk of placental thrombosis, thus improving pregnancy outcomes in high-risk subjects [25]. However, heparin seems to not exert an anticoagulant effect on the placental tissue since its administration does not improve placental thrombotic injury rate [26]. Interestingly, heparin improves pregnancy outcomes with a decrease of placental-mediated complications also in women without thrombophilia [25,27]. In a recent systematic review and meta-analysis, Rodger and colleagues reported that LMWH reduces the risk of preeclampsia recurrence, indicating LMWH as a promising therapeutic tool for PE syndrome [28]. However, heparin use for preeclampsia treatment is still controversial and its placental mechanism of action is unclear. It has been proposed that the beneficial effects of LMWH on PE patients are correlated to an anti-inflammatory action. Heparin and its derivatives have been demonstrated to be effective against several inflammatory experimental conditions as mouse models of colitis [29], arthritis [30] and in patient with airways inflammatory disease [31]. Furthermore, it has been shown that, in an inflammation-model of mice treated with LPS, modified heparin with low/absent anticoagulatory capacity strongly inhibited expression of hepcidin, serum iron uptake regulator whose levels rise during inflammation [32].

Importantly, it has been demonstrated in vitro that heparin reduces HMGB1 affinity for RAGE [33,34]. HMGB1 possesses heparin-binding ability [35] and it undergoes conformational change when mixed with LMWH [34]. Moreover, HMGB1-stimulated macrophages and Human 
Umbilical Vein Endothelial Cells (HUVEC) reduce IL-6 and TNF- $\alpha$ release when treated by heparin in a dose-dependent manner [34].

Our hypothesis is that LMWH inhibition of the placental pro-inflammatory HMGB1/RAGE axis could contribute to the anti-inflammatory activity observed in heparin-treated pre-eclamptic patients. In the present study, we evaluated placental HMGB1 and RAGE expression in physiological and PE pregnancies and we investigated whether LMWH could modify placental HMGB1 and RAGE expression and/or their binding ability in the human placental tissue.

\section{Results}

\subsection{Study Population}

Clinical features of the study population are reported in Table 1. Physiological $(n=19)$ and PE $(n=18)$ patients were comparable in terms of maternal age and parity. As expected, PE group was characterized by significantly lower gestational age $(p<0.001)$, birth weight $(p<0.01)$ and placental weight at delivery $(p<0.001)$ relative to control pregnancies.

Table 1. Clinical features of the study population. Values are expressed as median (range) and percentage. A.G.A, appropriate for gestational age; FGR, fetal growth restriction; n.s. not significant.

\begin{tabular}{|c|c|c|c|}
\hline & $\begin{array}{l}\text { Physiological } \\
\quad(n=19)\end{array}$ & $\begin{array}{l}\text { Preeclampsia } \\
\qquad(n=18)\end{array}$ & $p$ Value \\
\hline Nulliparae (\%) & 47.36 & 50 & n.s. \\
\hline Gestational age at delivery (weeks) & $39.4(38-41)$ & $32.8(28-37)$ & $<0.001$ \\
\hline Maternal age at delivery (years) & $34(23-39)$ & $34(20-41)$ & n.s. \\
\hline \multicolumn{4}{|l|}{ Ethnicity $(\%)$} \\
\hline Caucasian & 89.47 & 86.33 & n.s. \\
\hline \multicolumn{4}{|l|}{ Prenatal medications (\%) } \\
\hline Albumin & - & 11.11 & n.s. \\
\hline Antibiotics & 42.1 & 16.67 & n.s. \\
\hline Antidepressant & - & - & - \\
\hline Diuretics & - & 16.67 & n.s. \\
\hline Eutirox & 5.26 & - & n.s. \\
\hline Folin & 84.21 & 94.44 & n.s. \\
\hline Heparin & 5.26 & 16.66 & n.s. \\
\hline Iron & 15.79 & 5.55 & n.s. \\
\hline Proton Pump Inhibitors (PPIs) & 5.26 & 11.11 & n.s. \\
\hline Ventolin & - & - & - \\
\hline Smokers (\%) & 15.78 & 16.67 & n.s. \\
\hline Alcohol (\%) & 10.52 & 16.67 & n.s. \\
\hline Previous prenatal admission (\%) & 5.26 & 16.67 & n.s. \\
\hline Systolic Blood pressure (mm Hg) & $120(90-140)$ & $162.5(130-180)$ & $<0.001$ \\
\hline Diastolic Blood pressure (mm Hg) & $75(60-90)$ & $100(85-117)$ & $<0.001$ \\
\hline Proteinuria $(\mathrm{g} / 24 \mathrm{~h})$ & Absent & $1.2(0.33-8.28)$ & $<0.001$ \\
\hline $\mathrm{A} / \operatorname{REDF}(\%)$ & 0 & 50 & $<0.001$ \\
\hline Pathological Uterine Doppler (\%) & 0 & 66.67 & $<0.001$ \\
\hline Labor $(\%)$ & 63 & 17 & $p=0.032$ \\
\hline Antibiotics in labor (\%) & 31.58 & 83.33 & $p=0.04$ \\
\hline Delivery to processing (range in hours) & $0-3$ & $0-3$ & \\
\hline Caesarean section $(\%)$ & 37 & 83 & $p=0.011$ \\
\hline Anesthesia (\%) & 63.15 & 83.33 & n.s. \\
\hline Local & 25 & - & \\
\hline Spinal & 58.33 & 93.33 & $n-0044$ \\
\hline Epidural & 16.67 & - & $p=0.044$ \\
\hline General & - & 6.67 & \\
\hline Maternal oxygen given at delivery? (\%) & - & 16.67 & n.s. \\
\hline Birth weight $(\mathrm{g})$ & $3550(2920-4020)$ & $\begin{array}{l}\text { AGA }(n=5): 2150(1110-3180) \\
\text { FGR }(n=13): 1250(610-1880)\end{array}$ & $<0.001$ \\
\hline Placental weight (g) & $580(450-845)$ & $310(184-650)$ & $<0.001$ \\
\hline Fetal sex $(\%)$ & & & $p=0.061$ \\
\hline Male & 57.9 & 22.2 & \\
\hline Female & 42.1 & 77.8 & \\
\hline Magnesium sulfate (\%) & - & 27.78 & $p=0.02$ \\
\hline
\end{tabular}


The presence of fetal-placental compromise was evaluated by Doppler velocimetry of umbilical and uterine arteries. PE patients had abnormal Doppler velocimetries of umbilical or uterine (50\% and $66.67 \%$ respectively) arteries, while in eight PE patients $(44.44 \%$ ) both values were pathological. In our study population, LMWH was given during pregnancy to one patient of the control group (5.26\%) and to three patients of the PE group (16.66\%).

\subsection{HMGB1 and RAGE Expressions in Physiological and Pre-Eclamptic Placentae}

HMGB1 has been widely studied for its ability in stimulating pro-inflammatory cytokines by binding to its receptor RAGE. Since pre-eclampsia is characterized by exacerbated placental inflammation, we investigated HMGB1 and RAGE expression in PE compared to physiological placentae.

We reported a significant increase of HMGB1 mRNA levels in PE vs. physiological placentae ( $p=0.018,2.67$ fold increase, Figure 1A, left panel). Data were confirmed at the protein level where we found a 1.76 Fold Increase in PE placentae relative to controls ( $p=0.001$, Figure 1A, right panel). Western blot analysis for RAGE did not reveal difference in its protein expression between pathological and control tissues (Figure 1B).

A

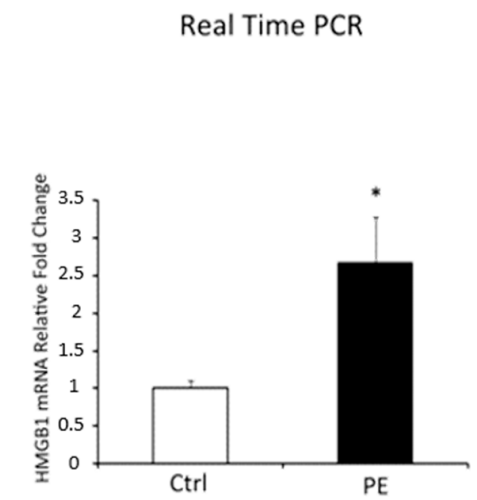

HMGB1

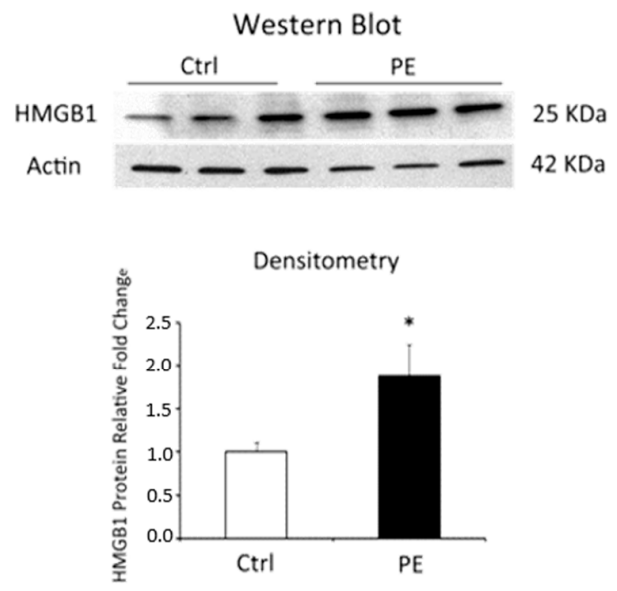

B

RAGE

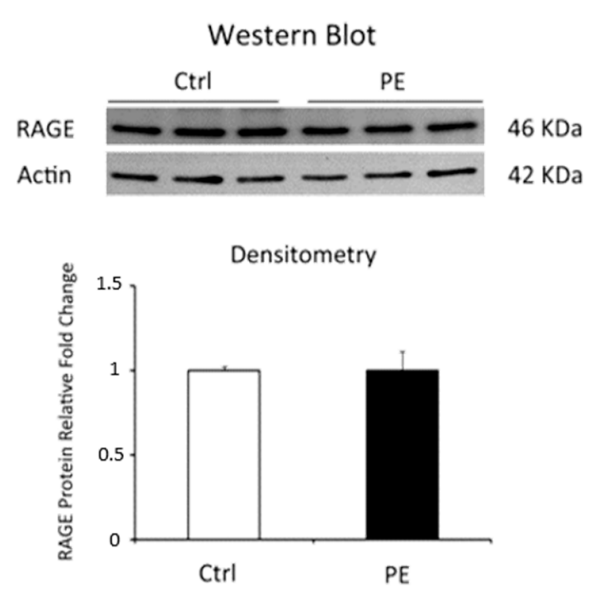

Figure 1. HMGB1 and RAGE expression levels in normal $(\mathrm{N}=19)$ versus $\mathrm{PE}(\mathrm{N}=18)$ placentae. (A) HMGB1 mRNA (left panel) and protein (right panel) expression levels as assessed by Real Time PCR and western blot analysis; (B) RAGE protein expression assessed by western blot. Statistical significance $\left.{ }^{*}\right)$ has been considered as $p<0.05$. 
Since PE is often associated with Fetal Growth Restriction (FGR) [36,37], we investigated whether HMBG1 expression in PE placentae could be related to fetal growth. We found no significant differences in placental HMGB1 expression between PE with Appropriate for Gestational Age (AGA) fetuses PE-FGR placentae ( $p>0.05$, Figure S1A). Importantly, PE-AGA and PE-FGR placentae were both characterized by higher gene (PE-AGA vs. Ctrl, $p=0.296,3.29$ Fold Increase; PE-FGR vs. Ctrl, $p=0.019$, 2.41 Fold Increase, Figure S1A) and protein (PE-AGA vs. Ctrl, $p=0.028,1.72$ Fold Increase; PE-FGR vs. Ctrl, $p=0.02,1.77$ Fold Increase, Figure S1B) HMGB1 expression levels relative to physiological controls.

Next, we compared HMGB1 levels in early-onset versus late-onset PE in order to highlight a possible relation between HMGB1 expression and gestational age during preeclampsia. We did not find significant differences in HMGB1 gene and protein expression levels between early- and late-onset PE ( $p>0.05$, Figure S2A,B).

Finally, since labour is a pro-inflammatory condition [38], we investigated whether HMGB1 expression was affected by the onset of labour. No significant differences were found in HMGB1 mRNA and protein levels in placentae from patients in labour relative to those that underwent caesarean section (CS) in both control and PE groups $(p>0.05$, Figure S3A,B).

\subsection{LMWH Effect on HMGB1 and RAGE Expression in Physiological Human Villous Explants}

Low Molecular Weight Heparin, widely known for its anti-coagulant properties, has beneficial effects on PE patients that look correlated to an unspecified anti-inflammatory activity. Therefore, we next investigated whether LMWH could modulate placental HMGB1-mediated inflammation in physiological tissues. Since recent evidences demonstrated that LMWH dose-response is highly variable [39], we tested LMWH effects at 24 and $48 \mathrm{~h}$ using concentrations of 0.5 and 5 units $/ \mathrm{mL}$ to span the range of maternal circulating plasma levels found in pregnant women receiving subcutaneous injections of prophylactic (5000 units/day; equivalent to 0.25 units/mL) or therapeutic (more than 10,000 units/day; equivalent to 2.5 units/mL) doses [40,41]. 5 U of LMWH resulted toxic to our model as we reported, as a sign of tissue degradation, an abnormally low expression of housekeeping gene $18 \mathrm{~S}$ (data not shown). Therefore, we considered only data obtained from 0.5 U LMWH-treated explants. After $24 \mathrm{~h}$, we found significantly increased HMGB1 gene expression in treated compared to control explants ( $p=0.001,2.32$ fold increase, Figure 2A). In contrast, we found a significant decrease of HMGB1 gene expression in $48 \mathrm{~h}$ in LMWH-treated explants relative to controls ( $p=0.036,2.22$ fold decrease, Figure 2A). Data were confirmed at the protein level by western blot analysis. We found a significant increase in HMGB1 protein levels ( $p=0.029,2.5$ fold increase, Figure $2 \mathrm{~B})$ at $24 \mathrm{~h}$ that markedly decreased at $48 \mathrm{~h}$ in LMWH explants versus controls ( $p>0.05,1.78$ fold decrease, Figure 2B).

Finally, we investigated whether LMWH could modulate RAGE expression. Western blot data showed no significant differences in RAGE protein levels between LMWH-treated and untreated explants at $24 \mathrm{~h}$, while RAGE protein expression was significantly inhibited at $48 \mathrm{~h}$ after LMWH treatment ( $p=0.014,1.85$ Fold decrease) (Figure 3). Our findings suggest the ability of LMWH to modulate both HMGB1 and RAGE expression in term human placental villous explants. 


\section{HMGB1}

A

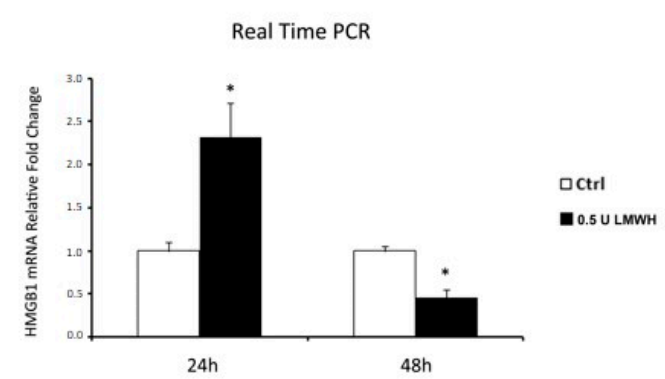

B

Western Blot
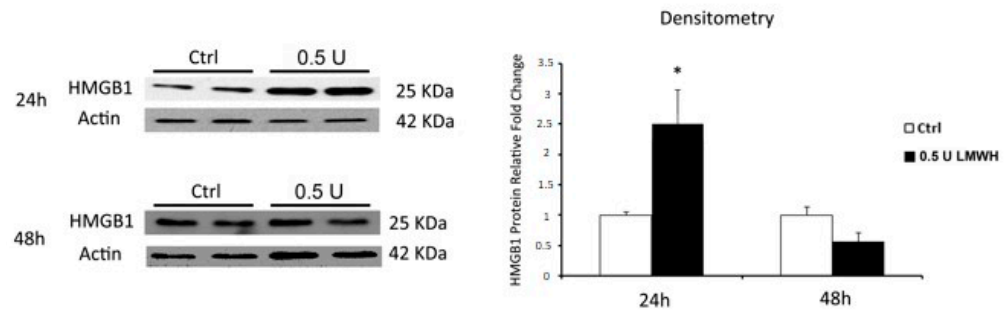

Figure 2. HMGB1 expression in LMWH-treated vs. untreated physiological placental villous explants. (A) HMGB1 mRNA expression levels in placental villous explants treated for $24 \mathrm{~h}$ ( $\operatorname{ctrl} \mathrm{n}=8$ and $0.5 \mathrm{U}$ LMWH $\mathrm{n}=10$ ) and $48 \mathrm{~h}$ (ctrl $\mathrm{n}=11$ and $0.5 \mathrm{U}$ LMWH $\mathrm{n}=10$ ) by $0.5 \mathrm{U}$ of LMWH or plain culture medium, assessed by Real Time PCR; (B) Representative western blot for HMGB1 protein expression in LMWH-treated vs. untreated placental villous explants for $24 \mathrm{~h}(\operatorname{ctrl} \mathrm{n}=4$ and $0.5 \mathrm{U}$ LMWH $\mathrm{n}=4)$ and $48 \mathrm{~h}(\operatorname{ctrl} \mathrm{n}=10$ and $0.5 \mathrm{U}$ LMWH $\mathrm{n}=10)$. Statistical significance $\left.{ }^{*}\right)$ has been considered as $p<0.05$.

\subsection{5 U LMWH Treatment Did Not Affect Physiological Term Placental Villous Explants Viability}

To evaluate whether 0.5 U LMWH affects placental explants viability, we performed the Lactate Dehydrogenase (LDH) assay. This test determines cell membrane integrity by measuring cellular LDH release/leakage. After $24 \mathrm{~h}$ and $48 \mathrm{~h}$ of treatment, we observed that the relative LDH amount released into the media was comparable among basal culture medium treated explants and those treated by $0.5 \mathrm{U}$ LMWH $(p>0.05$, Figure S4). Importantly, LDH levels in all treated explants were significantly lower compare with the cytotoxicity cut-off value of $41 \%$ ranging from 0.13 to $0.56 \% \mathrm{LDH}$ release $(p<0.05$, Figure S4). Therefore, $0.5 \mathrm{U}$ LMWH treatment does not affect cell viability $(p<0.05$, Figure S4).

\subsection{LMWH Inhibits HMGB1/RAGE Interaction}

HMGB1 pro-inflammatory effect is mediated by its interaction with RAGE. Indeed, we investigated the ability of HMGB1 to bind its receptor after 24/48 h LMWH treatments. To reach our goal we performed RAGE immunoprecipitation followed by HMGB1 western blot. We found a significant decrease in HMGB1 protein levels $(p=0.011,1.27$ fold decrease, Figure 4A) in $24 \mathrm{~h}$ LMWH-treated explants. In contrast, we found no differences of HMGB1 relative to untreated controls in 48 h-treated villous explants (Figure $4 \mathrm{~A}$ ). To further confirm our findings, we also determined HMGB1 protein levels in the IP supernatants. Western blot analysis revealed a significant increase of free HMGB1 in the supernatants at both 24-48 h LMWH-treated explants compared to untreated controls ( $p<0.001$ and $p=0.017$ respectively, 3.17 and 1.61 fold increases, respectively, Figure 4B). 


\section{RAGE}

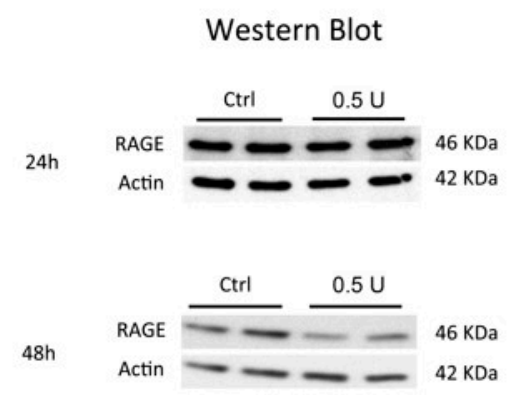

Densitometry

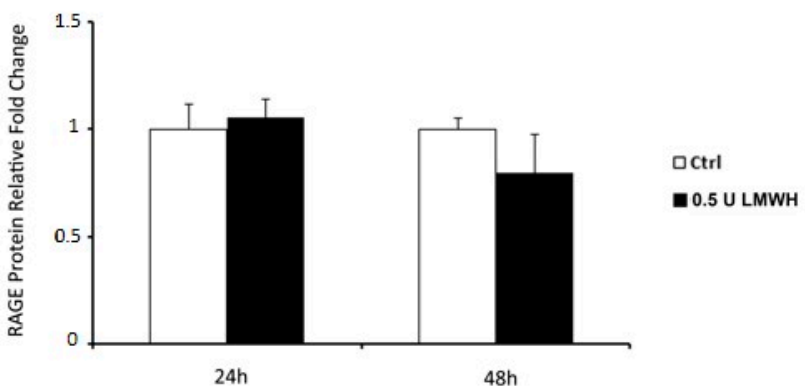

Figure 3. RAGE expression in LMWH-treated vs. untreated physiological placental villous explants. Representative western blot for RAGE protein expression level in physiological term placental villous explants treated for $24 \mathrm{~h}(\operatorname{ctrl} \mathrm{n}=7$ and $0.5 \mathrm{U}$ LMWH $\mathrm{n}=7)$ and $48 \mathrm{~h}(\operatorname{ctrl} \mathrm{n}=10$ and $0.5 \mathrm{U}$ LMWH $\mathrm{n}=10)$ by $0.5 \mathrm{U}$ of LMWH.

\subsection{HMGB1 Immunofluorescent Staining in Physiological Placental Villous Explants}

Next, to elucidate which villous cell population was most responsive to LMWH treatment in terms of HMGB1 expression, we performed HMGB1 immunofluorescence in $24 \mathrm{~h}$ treated and control explants. HMGB1 operates as transcription factor when it is localized in the nucleus, while it acts as a pro-inflammatory cytokine when released from the cytoplasm to the extracellular environment. HMGB1 IF staining was mainly localized in mesenchymal (M) and endothelial cells and absent in the syncytiotrophoblast (TR) layer (Figure 5A-C). Importantly, IF confirmed RNA and protein data at $24 \mathrm{~h}$ of LMWH treatment. Immunoreactivity for HMGB1 was markedly increased in mesenchymal and endothelial cells nuclear, peri-nuclear and cytoplasmic areas in LMWH-treated explants (Figure 5B-D) relative to untreated controls (Figure $5 \mathrm{~A}-\mathrm{C}$ ). 
HMGB1

A

Immunoprecipitation
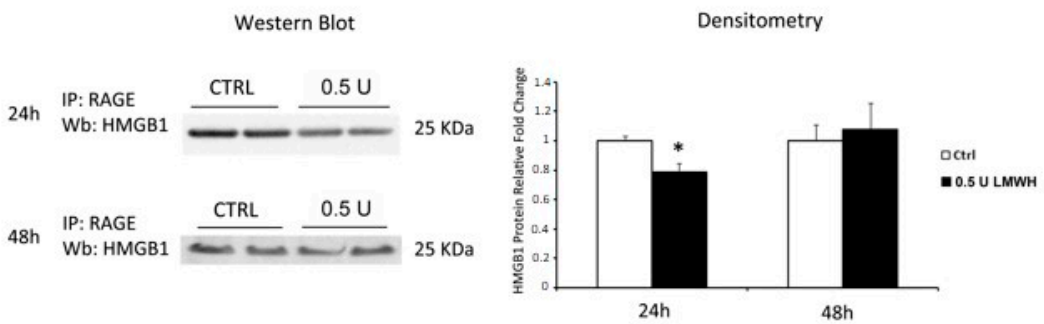

B

Supernatant

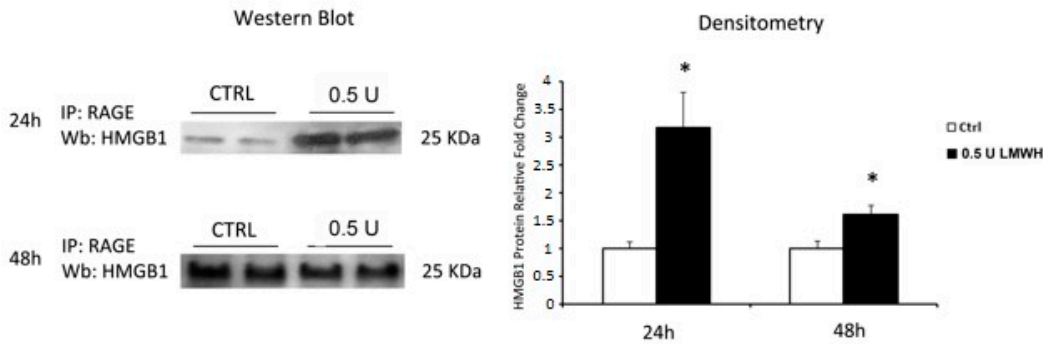

Figure 4. RAGE/HMGB1 binding in LMWH-treated vs. untreated placental villous explants. HMGB1 protein levels were evaluated by western blot after immunoprecipitation with RAGE antibody of protein lysates from placental villous explants treated by $0.5 \mathrm{U}$ of LMWH for $24 \mathrm{~h}$ and $48 \mathrm{~h}$. (A) Representative WB for HMGB1 protein levels after RAGE IP at $24 \mathrm{~h}(\operatorname{ctrl} \mathrm{n}=16$ and $0.5 \mathrm{U}$ LMWH $\mathrm{n}=15)$ and $48 \mathrm{~h}$ ( $c$ trl $n=5$ and 0.5 U LMWH n =6); (B) Representative WB for HMGB1 protein levels in RAGE IP supernatant at $24 \mathrm{~h}(\operatorname{ctrl} \mathrm{n}=8$ and $0.5 \mathrm{U} \mathrm{LMWH} \mathrm{n}=10)$ and $48 \mathrm{~h}(\operatorname{ctrl} \mathrm{n}=5$ and $0.5 \mathrm{U}$ LMWH $\mathrm{n}=6)$. Statistical significance ${ }^{*}$ ) has been considered as $p<0.05$.

\subsection{IL-6 and TNF $\alpha$ Gene Expression in Physiological Placental Villous Explants}

Finally, since we established that LMWH could impair HMGB1/RAGE binding, we examined by Real Time PCR the expression of HMGB1 target genes IL-6 and TNF $\alpha$ in placental villous explants treated by $0.5 \mathrm{U}$ LMWH or basal culture medium for 24 or $48 \mathrm{~h}$. We focused on gene expression to emphasize HMGB1 role as transcriptional activator. Accordingly to HMGB1 expression, we found significantly higher IL-6 ( $p=0.04,2.7$ fold increase, Figure $6 \mathrm{~A})$ and TNF $\alpha(p=0.02,2.13$ fold increase, Figure 6B) mRNA levels at $24 \mathrm{~h}$ in LMWH-treated explants vs. controls. No significant differences were found in IL-6 and TNF $\alpha$ gene expression levels in $48 \mathrm{~h}$ LMWH-treated explants vs. controls (Figure 6A,B), even though it was evident a trend of reduction in both genes after LMWH administration. Importantly, considering LMWH treated explants, we found significantly lower IL-6 $(p=0.037,3.4$ fold decrease, Figure 6A) and TNF $\alpha(p=0.02,2.7$ fold increase, Figure 6B) mRNA levels in $48 \mathrm{~h}$ vs. $24 \mathrm{~h}$ group. 


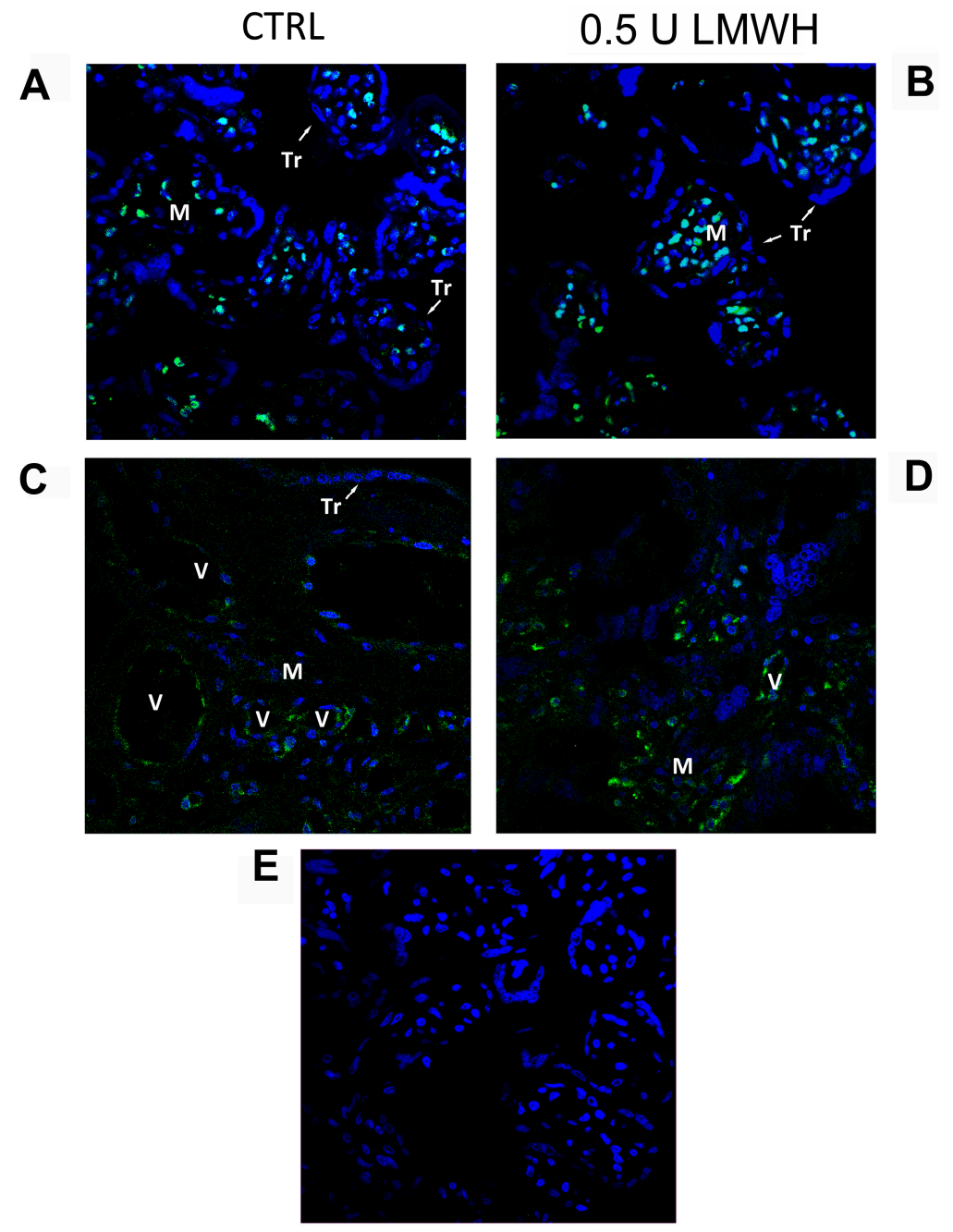

Figure 5. HMGB1 spatial localization in untreated or $0.5 \mathrm{U}$ LMWH treated physiological villous explants assessed by immunofluorescent staining. (A-C) HMGB1 spatial localization in untreated $(n=6)$ physiological villous explants assessed by immunofluorescent staining; (B-D) HMGB1 spatial localization in physiological villous explants treated with $0.5 \mathrm{U}$ of LMWH $(n=6)$; $(\mathrm{E})$ Absence of positive immunoreactivity for HMGB1 in section stained with control IgG. Cell nuclei are showed in blue by DAPI signal. TR, trophoblast cells; M, mesenchyme; V, vessel. Original magnifications, $60 \times$.

A

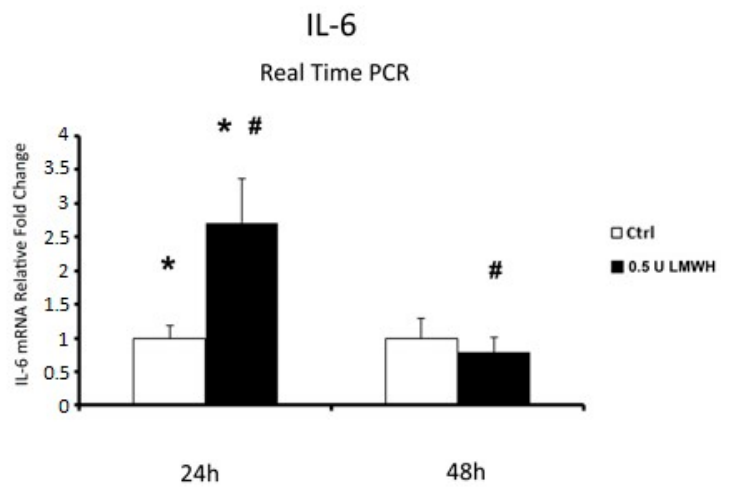

Figure 6. Cont. 


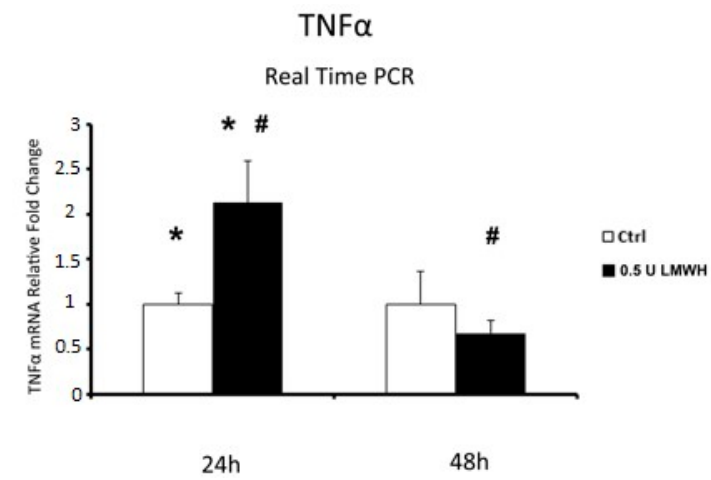

Figure 6. IL-6 and TNF $\alpha$ mRNA expression in LMWH-treated explants vs. controls assessed by Real Time PCR. (A) IL-6 gene expression in villous explants treated by $0.5 \mathrm{U}$ of LMWH for $24 \mathrm{~h}$ (ctrl $\mathrm{n}=8$ and $0.5 \mathrm{U}$ LMWH $\mathrm{n}=10)$ and $48 \mathrm{~h}(\operatorname{ctrl} \mathrm{n}=11$ and $0.5 \mathrm{U}$ LMWH $\mathrm{n}=10)$. (B) TNF $\alpha$ gene expression levels in villous explants treated by $0.5 \mathrm{U}$ of LMWH for $24 \mathrm{~h}(\operatorname{ctrl} \mathrm{n}=8$ and $0.5 \mathrm{U}$ LMWH $\mathrm{n}=10)$ and $48 \mathrm{~h}(\operatorname{ctrl} \mathrm{n}=11$ and $0.5 \mathrm{U}$ LMWH $\mathrm{n}=10)$. Statistical significance $\left({ }^{*} \#\right)$ has been considered as $p<0.05$.

\section{Discussion}

In the present study, we reported increased expression of HMGB1, a potent inducer of pro-inflammatory cytokines, in placentae from pregnancies complicated by pre-eclampsia compared to physiological controls. We did not find differences in the expression of HMGB1's receptor RAGE in PE tissues relative to controls. Next, we evaluated LMWH effect on HMGB1/RAGE expression and association as well as on HMGB1 target genes IL- 6 and TNF $\alpha$ in a physiological placental villous explants model. After 24 h, LMWH promoted HMGB1, IL-6 and TNF $\alpha$ while it did not influence RAGE expression. Importantly, HMGB1/RAGE binding was inhibited by LMWH at $24 \mathrm{~h}$, as further demonstrated by the accumulation of free HMGB1 in treated explants. Finally, HMGB1, RAGE, IL-6 and TNF $\alpha$ were down-regulated at $48 \mathrm{~h}$ after $0.5 \mathrm{U}$ LMWH treatment. Our data indicate that LMWH modulates the HMGB1/RAGE pro-inflammatory axis in the human placenta.

HMGB1 placental expression was first reported in 2007 by Holmlund and colleagues, that described its localization in both syncithiotrophoblast and chorionic mesenchyme [20]. Herein we reported a significant over-expression of HMGB1 in PE placentae, characterized by exacerbated inflammation. In accordance to our results, Wang and colleagues previously reported increased HMGB1 levels in the placentae, but not in the serum, of pre-eclamptic patients [20,21]. Importantly, they found no association between gestational age and HMGB1 serum concentration [21], hypothesizing that the lack of correlation between placental and systemic HMGB1 levels could be due to a source of circulating HMGB1 different from the placenta and/or to the elevated serum levels of soluble RAGE (sRAGE) in PE [21,42]. Their PE patients were selected by means of systolic/diastolic blood pressure $>140 / 90 \mathrm{mmHg}$ and proteinuria $>0.3 \mathrm{~g} / 24 \mathrm{~h}$ and no stratification of severe cases was made. In contrast, Holmlund and colleagues included severe cases (systolic/diastolic blood pressure $>160 / 110$ and proteinuria $>3 \mathrm{~g} / 24 \mathrm{~h}$ ) but they did not find a correlation with HMGB1 placental expression and PE severity [20].

The elevated HMGB1 levels that we described in the pre-eclamptic placental tissue could contribute to the pro-inflammatory cytokines production and/or they could be a consequence of the placental ischemic damage typical of PE. Recently, it was reported that serum HMGB1 levels are increased in pregnant relative to non-pregnant women and that this increase is more dramatic in PE, without differences between moderate and severe pre-eclampsia [43]. In line with these data, herein we demonstrated that placental HMGB1 increase during pre-eclampsia is not related to the presence of fetal growth restriction. In accordance to our results, Chen and colleagues reported no significant difference in HMGB1 levels between PE-AGA and PE-FGR placentae [44]. Taken together, all these findings suggest the presence of a common pathogenesis between PE-AGA and PE-FGR pregnancies. 
We did not find any association between PE onset (early or late) and HMGB1 expression levels. Our data are in agreement with Chen and colleagues that, using semi-quantitative analysis of the immunohistochemistry and western blotting, showed no significant differences in the levels of HMGB1 in the syncytiotrophoblast from early-onset relative to late-onset PE and control pregnancies [44]. Importantly, in the present study we focused only on the last trimester of pregnancy since it is correlated to the onset of PE clinical symptoms. Our future investigation will be consider HMGB1 expression throughout gestation.

Elevated HMGB1 was observed in pregnant women with other pro-inflammatory conditions as obesity [45] and pre-term labor [46]. It is well established that labour is associated to a pro-inflammatory systemic response [38]. Since HMGB1 is a potent inflammatory cytokine, we investigated placental HMGB1 expression in labour versus caesarean section deliveries, but no differences were observed in both control and PE groups. In line with our results, Holmlund and colleagues described no significant differences in HMGB1, RAGE, TLR2 or TLR4 expression between labour and CS placentae [20].

Thus, different stress stimuli, not only of placental origin, could be responsible for the elevated HMGB1 levels observed. It was shown that JEG-3 choriocarcinoma cells expressed and released large amount of HMGB1 under PE-like hypoxic conditions [47], suggesting a possible involvement of placental HMGB1 in the instauration of the PE exacerbated inflammation $[48,49]$.

Extracellular HMGB1 exerts its cytokine-like activity by binding to RAGE receptor. RAGE increases with pregnancy onset and it is further augmented in the PE myometrium [22]. Moreover, RAGE protein expression was found significantly higher in syncithiotrophoblast and endothelial cells of PE placentae relative to controls [50]. In stark contrast, herein we did not find differences in RAGE expression between PE and control placentae. In accordance with our findings, other groups found abundant RAGE expression in trophoblast and decidua of normal term placentae but no differences in PE versus normal tissues [20]. Variable results could be due to differences in the specimens used. We analyzed the whole placental tissue instead of isolated trophoblast or endothelial cells.

Several evidences indicate beneficial effects of LMWH for PE treatment. LMWH seems to improve the maternal-fetal outcomes [27] and to reduce pregnancy-complications recurrence [28]. Moreover, LMWH effects are unrelated to the heparin anti-coagulatory activity [26,27]. It has been shown in vitro that conditioned media from heparin-treated placental villi exerted a pro-angiogenic activity on Human Umbilical Vein Endothelial Cells (HUVECs) [40] and that LMWH promotes trophoblast turnover by stimulating cytotrophoblast proliferation and syncytial fusion [41]. However, Drewlo and colleagues demonstrated that LMWH could stimulate the placental expression and release of anti-angiogenic soluble Vascular Endothelial Growth Factor (VEGF) receptor-1 (sFLT) and thus they recommended caution for LMWH use during severe PE [41].

Indeed, LMWH use is controversial and its mechanism of action on the placental tissues is still unclear. In vitro studies suggested LMWH ability to reduce trophoblast apoptosis through the modulation of anti-apoptotic B-cell lymphoma (Bcl-2) family molecules [51] and to promote the invasiveness of extravillous trophoblast by enhancing Matrix metalloprotease-2 (MMP-2), heparin binding-Epidermal Growth Factor (HB-EGF) and cysteine-rich angiogenic inducer 61 (Cyr61) activities [52]. Herein, we reported LMWH ability to modulate the pro-inflammatory HMGB1/RAGE axis in physiological term placental tissues. We found that HMGB1/RAGE interaction was inhibited by LMWH after $24 \mathrm{~h}$ of treatment as demonstrated by immunoprecipitation assay. This effect could be due to the LMWH-induced HMGB1 conformational change previously demonstrated in vitro [34]. Since RAGE binds heparin too [33], we could not exclude that LMWH could have blocked also the HMGB1 receptor.

Furthermore, HMGB1/RAGE complex could modulate NFkB activation that, in turn, promotes RAGE expression [53]. Thus, RAGE reduction reported herein at $48 \mathrm{~h}$ of treatment could be directly due to LMWH-mediated inhibition of HMGB1/RAGE complex. The initiation of a pro-inflammatory loop by HMGB1 has been suggested in several models of pathological inflammation as multiple sclerosis [54], necrosis [55] and preterm birth [56]. In PE, LMWH might be able to slow or even stop 
the HMGB1-induced pro-inflammatory loop preventing the exacerbation of inflammation typical of this syndrome.

Taken together, our data confirm the ability of low molecular weight heparin to block the HMGB1/RAGE interaction in vitro in placental villous explants. One limitation of the present study is that we did not experimentally confirm the LMWH-induced HMGB1 conformational change. Moreover, HMGB1 possesses other receptors like the Toll Like Receptor (TLR) 2 and TLR4 that lead to NFkB nuclear translocation as well [57,58]. It has been recently demonstrated that 2-O, 3-O-desulfated heparin, characterized by significant anti-inflammatory but minimal anti-coagulatory properties, is able to inhibit HMGB1 interaction with TLR2 and TLR4 [59]. Indeed, TLR2 and TLR4 could have contributed to the heparin-driven modifications reported in the present study. Further investigations are required.

Since its discovery in the late 1990s, HMGB1 was mainly considered as a nuclear protein but evidences were accumulating about its extracellular cytokine-like function. Similar to other cytokines, HMGB1 is pleiotropic with cell-specific activities in the placental tissue [20]. Previous data showed that HMGB1 induced migration and sprouting in endothelial cell and promoted trophoblast invasiveness [60,61]. Zhu and colleagues reported HMGB1 cytoplasmatic localization in the PE placenta while in physiological term pregnancies it was described in the placental nuclei [62]. These data suggest that nuclear-cytoplasmatic translocation may participate in the pathogenetic process of Preeclampsia. In line with these results, we found a stronger nuclear/perinuclear HMGB1 signal relative to the cytoplasm. In all LMWH-treated and untreated physiological term placental explants. Moreover, we showed that HMGB1 signal was mainly localized in the chorionic mesenchyme and endothelial cells. Our findings are in accordance with Holmlund and colleagues that found HMGB1 nuclear expression in both chorionic mesenchyme and endothelial cells $[20,60]$. In contrast, previous studies described a strong HMGB1 positivity in both syncytiotrophoblast and extravillous trophoblast [20,62].

The activation of HMGB1/RAGE pathway promotes the transcription of IL- 6 and TNF- $\alpha[34,53]$. In our model, the inhibition of IL- 6 and TNF- $\alpha$ expression was evident after $48 \mathrm{~h}$ of LMWH-treatment. Taken together, our data confirmed the ability of low molecular weight heparin to block HMGB1/RAGE interaction and the expression of their target genes in an in vitro model of placental villous explants. The increase in HMGB1, IL6 and TNF $\alpha$ expression at $24 \mathrm{~h}$ in response to LMWH suggest an initial inflammatory stress being counteracted by heparin as demonstrated by the inhibition of HMGB1/RAGE binding reported in the present study. It is well established that heparin could directly modify HMGB1 structure altering its interaction with RAGE, that in turn leads to a decrease of IL-6 and TNF- $\alpha$ expression [34]. Importantly, HMGB1 transcription itself is stimulated by pro-inflammatory TNF- $\alpha$ [63] as well as TNF- $\alpha$ could promote HMGB1 release from inflammatory cells $[14,64]$. Thus, the inhibition of TNF- $\alpha$ production exerted by LMWH could have indirectly contributed to HMGB1 down-regulation that we reported.

In conclusion, our data depicted a new molecular mechanism through which LMWH exerts its anti-inflammatory activity on the placental tissue. We underlined the importance of the HMGB1/RAGE axis in the placental inflammatory response thus opening new directions in the investigation of PE pathogenesis and management. Indeed, targeting HMGB1 could be effective to control the ischemia-related inflammatory damage typical of this syndrome, as already demonstrated in other pathological models [65-67]. Further investigation is required.

\section{Materials and Methods}

\subsection{Ethics Statement and Place of Recruitment}

This study was conducted according to the principles expressed in the Declaration of Helsinki. The study was approved by the Institutional Review Board of O.I.R.M. S. Anna Hospital and "Ordine Mauriziano di Torino" (n 337; protocol 11552/C.28.1 07/12/2010) (Turin, Italy). All patients were 
recruited at O.I.R.M S. Anna Hospital (Turin, Italy) and provided written informed consent for the collection of samples and subsequent analysis.

\subsection{Study Population and Tissues Collection}

The study populations included pre-eclamptic singleton pregnancies $(n=18)$ and physiological control term pregnancies $(\mathrm{n}=19)$. PE was defined by presence of pregnancy-induced hypertension (systolic $>140 \mathrm{mmHg}$, diastolic $>90 \mathrm{mmHg}$ ) and proteinuria ( $>300 \mathrm{mg} / 24 \mathrm{~h}$ ) after the 20th weeks of gestation in previously normotensive women [1]. Fetal Growth Restriction (FGR) was defined as birth weight below the fifth centile according to the Italian growth curves normalized for gestational age and sex $[36,37]$ accompanied by pathological umbilical artery Doppler waveforms (absent or reverse end diastolic flow-A/REDF) and/or increased resistance to flow in maternal uterine arteries (early diastolic notch or pulsatility index-PI—more than 0.58). Early-onset PE was defined as preeclampsia that develops before 34 weeks of gestation, whereas late-onset preeclampsia develops at or after 34 weeks of gestation [68]. Physiological controls were obtained from normal term healthy singleton pregnancies that did not show any signs of preeclampsia or other placental disease. We did not use "age-matched" control pregnancies since no pre-term delivery is physiological. Patients with cardiovascular diseases, diabetes, metabolic syndrome, infections, kidney disease, congenital malformations and chromosomal anomalies (number and/or structure) were excluded. Placental tissue biopsies were randomly collected from the basal plate and snap frozen immediately after delivery. Calcified, necrotic and visually ischemic areas were excluded from collection. Eight additional physiological term placentae were collected and processed for placental villous explants preparation as described below.

\subsection{Human Chorionic Villous Explants Cultures and LMWH Treatment}

Biopsies from physiological term placentae $(n=8)$ were processed within $2 \mathrm{~h}$ from delivery. This model allowed us to determine the sequence of molecular events in healthy tissues characterized by conserved physiological pathways, thus avoiding biases due to previous existing pathological anomalies. Amniotic membranes were mechanically removed, and placental specimens were washed in cold phosphate-buffered saline (PBS) solution to eliminate excess of blood. Small portions of placental chorionic villi were excised and placed in a 24-well culture dishes (35 mg, $\mathrm{n}=142$ ). Explants were cultured in Ham's F12 media (Gibco by Life Technologies, Monza, Italy) and incubated at $37^{\circ} \mathrm{C}$ and $5 \% \mathrm{CO}_{2}$ to equilibrate overnight. Explants were then removed from the culture media and placed in $500 \mu \mathrm{L}$ of medium with different LMWH (Parnaparin, Alfa Wassermann, Bologna, Italy) concentrations: $0.5 \mathrm{U}$ and $5 \mathrm{U}$. Explants in basal culture medium were used as controls. Finally, control and treated explants were collected after $24 \mathrm{~h}$ or $48 \mathrm{~h}$ and immediately frozen for RNA and protein isolation $(n=130)$ or fixed for histological analyses $(n=12)$.

\subsection{Lactate Dehydrogenase (LDH) Cytotoxicity Assay}

Cytotoxicity of $0.5 \mathrm{U}$ LMWH treatment on villous explants was determined by LDH-Cytotoxicity colorimetric assay (Cat. No. K726-500, Biovision Inc., Milpitas, CA, USA) performed using $24 \mathrm{~h}$ and $48 \mathrm{~h}$ explants supernatant according to the manufacturer's instructions. Explants treated by Triton X-100 and by basal culture medium for $8 \mathrm{~h}$ were used as high $(\mathrm{H}, 100 \%)$ and low controls $(0 \%)$ respectively. The positive control (+) was provided by the manufacturer to test whether all reagents were working properly responding to active LDH enzyme. The absorbance at $450 \mathrm{~nm}$ was measured using a plate reader spectrophotomether. Percent cytotoxicity values were determined based on the amount of LDH released from 30-min readings, as follows: (test sample - low control)/(high control - low control $) \times 100$. The cut-off values for the LDH assay was determined by the $2 \times$ SD rule where the threshold is defined as $2 \times \mathrm{SD}$ beyond the mean of the screened samples. Values equal or exceeding the threshold were considered as sign of cytotoxicity. 


\subsection{RNA Isolation and Real Time PCR}

Total RNA was extracted from frozen placental biopsies and explants using TRI reagent (Sigma-Aldrich, Milano, Italy) according to manufacturer instructions and next treated with DNAse I to remove genomic DNA contamination. Three $\mu \mathrm{g}$ of total RNA were reverse transcribed using a random hexamers approach (Fermentas Europe, St. Leon-Rot., Germany). Gene expression levels of HMGB1, IL-6 and TNF $\alpha$ were quantified by Real-time PCR using specific TaqMan primers and probes following manufacturer's protocol (Life Technologies). For the relative quantitation, PCR signals were compared among groups after normalization using ribosomal 18S RNA expression as internal reference (Life Technologies). 18S mRNA expression was not affected by LMWH treatment. Relative expression and fold change were calculated according to Livak and Schmittgen [69].

\subsection{Western Blot Analysis}

Total proteins were isolated from placental biopsies and villous explants using 1X Radio Immuno-precipitation Assay (RIPA) buffer supplemented with Protease Inhibitors. Thirty $\mu g$ of protein were processed by SDS-page electrophoresis on 4-20\% polyacrylamide pre-cast gradient gels (Bio-Rad Laboratories S.r.l., Segrate, Italy). Next, proteins were transferred on polyvinylidene fluoride (PVDF) membranes and probed at room temperature with primary antibodies using the SnapID 2.0 system (Merck-Millipore, Vimodrone, Italy) following manufacturer instructions. The following primary antibodies were used: mouse monoclonal anti-human HMGB1 (1:1500 dilution, Sigma-Aldrich, Milano, Italy) and anti-human RAGE (1:500 dilution, Santa Cruz Biotechnology, D.B.A. Italia S.R.L, Segrate Italy). Biotinylated secondary antibodies were goat anti-mouse for HMGB1 and RAGE (1:20.000 dilution and 1:2000 dilution respectively, Santa Cruz Biotechnology, D.B.A. Italia S.R.L, Segrate Italy). Protein expression levels were normalized to $\beta$-actin by blotting with mouse monoclonal anti-human $\beta$-actin antibody (1:1000, Sigma-Aldrich, Milano, Italy). Blots were visualized using "Luminata Classico" Western HRP substrate (Merck-Millipore, Vimodrone Italy) for HMGB1 according to manufacturer's instructions and followed by densitometry.

\subsection{HMGB1 Immunofluorescence (IF) Staining}

0.5 U LMWH-treated $(n=6)$ and untreated $(n=6)$ villous explants were fixed in $4 \%$ paraformaldehyde and embedded in paraffin. Sodium citrate antigen retrieval was performed, followed by Sudan Black treatment $(0.1 \%$ Sudan Black in $70 \% \mathrm{EtOH})$ to quench endogenous fluorescence. Sections were pre-incubated in 5\% horse serum in PBS (contained 0.04\% sodium azide and $0.008 \%$ gelatin) to block nonspecific binding and incubated with primary antibodies overnight at $4{ }^{\circ} \mathrm{C}$. Mouse polyclonal antibodies anti-human HMGB1 (1:1000 dilution; Sigma-Aldrich, Milano, Italy) was used. Control IgG were used as negative controls. Slides were treated with $0.4 \%$ DAPI (4',6-diamidino-2-phenylindole) for nuclear detection. IF images were captured using Confocal Nikon D-Eclipse C1 microscope (Nikon, Chiyoda, Tokyo, Japan).

\subsection{Immunoprecipitation (IP) Assay}

Five hundred $\mu \mathrm{g}$ of total proteins from LMWH-treated and control villous explants were incubated with $2 \mu \mathrm{g}$ of anti-RAGE antibody for two hours at $4{ }^{\circ} \mathrm{C}$ on a rotor. Next, $20 \mu \mathrm{L}$ of G-PLUS-Agarose beads (Santa Cruz Biotechnology, D.B.A. Italia S.R.L., Segrate, Italy) were added to each sample before incubation overnight at $4{ }^{\circ} \mathrm{C}$ on a rotor. Samples were then centrifuged at $2500 \mathrm{rpm}$ for $5 \mathrm{~min}$ at $4{ }^{\circ} \mathrm{C}$ and the supernatants were removed. Pellets were then washed once with $500 \mu \mathrm{L}$ of PBS and next two times using $500 \mu \mathrm{L}$ of RIPA buffer plus protease inhibitors. Immunoprecipitates and supernatants were finally processed by western blot analysis for HMGB1 as reported above. 


\subsection{Statistical Analysis}

Clinical data are presented as median, range and frequencies (percentages) while in figures as mean and standard error (SE). To compare continuous variables, we used the Mann-Whitney $\mathrm{U}$ Test while for categorical variables the comparison between the 2 groups was done with $\chi^{2}$-test. Statistical test were carried out using the SPSS statistics version 20 software (IBM Inc., Armonk, NY, USA) and significance was accepted at $p<0.05$.

Supplementary Materials: Supplementary Materials are available online. Figure S1: HMGB1 expression levels in normal versus PE-AGA and PE-FGR placentae; Figure S2: HMGB1 expression levels in early-onset PE versus late-onset PE placentae; Figure S3: HMGB1 expression levels in control and PE placentas from women in labour and from women undergoing elective Caesarean sections (CS); Figure S4: 0,5 U LMWH effect on physiological term placental villous explants viability.

Acknowledgments: Low Molecular Weight Heparin (Parnaparin) was kindly provided by Alfa Wassermann (Bologna, Italy). Alessandro Rolfo is supported by Carlo Denegri Foundation (Italy). The authors would like to thank Annalisa Piazzese, Paola Re and Sara Paracchini (O.I.R.M Sant'Anna Hospital-Turin) for their support in patients recruitment and placental tissue collection.

Author Contributions: A.R. conceived and designed the experiments; C.Z., A.M.N., A.R. performed the experiments; A.R., D.G. and M.B. analyzed the data; T.T. and A.Z. contributed reagents/materials/analysis tools; C.Z., A.R. and A.Z. wrote the paper.

Conflicts of Interest: The authors declare no conflict of interest. The founding sponsors (Alfa Wassermann and Carlo Denegri Foundation) had no role in the design of the study; in the collection, analyses, or interpretation of data; in the writing of the manuscript, and in the decision to publish the results.

\section{References}

1. ACOG Committee on Obstetric Practice. ACOG Practice Bulletin. Diagnosis and management of preeclampsia and eclampsia. Number 33, January 2002. American College of Obstetricians and Gynecologists. Int. J. Gynaecol. Obstet. Off. Organ Int. Fed. Gynaecol. Obstet. 2002, 77, 67-75.

2. Redman, C.W.; Sargent, I.L. Latest advances in understanding preeclampsia. Science 2005, 308, $1592-1594$. [CrossRef] [PubMed]

3. Myatt, L.; Webster, R.P. Is vascular biology in preeclampsia better? J. Thromb. Haemost. 2009, 7, $375-384$. [CrossRef] [PubMed]

4. Sanchez-Aranguren, L.C.; Prada, C.E.; Riano-Medina, C.E.; Lopez, M. Endothelial dysfunction and preeclampsia: Role of oxidative stress. Front. Physiol. 2014, 5, 372. [CrossRef] [PubMed]

5. Smarason, A.K.; Sargent, I.L.; Starkey, P.M.; Redman, C.W. The effect of placental syncytiotrophoblast microvillous membranes from normal and pre-eclamptic women on the growth of endothelial cells in vitro. Br. J. Obstet. Gynaecol. 1993, 100, 943-949. [CrossRef] [PubMed]

6. Bianchi, M.E. Damps, pamps and alarmins: All we need to know about danger. J. Leukoc. Biol. 2007, 81, 1-5. [CrossRef] [PubMed]

7. Khan, R.N.; Hay, D.P. A clear and present danger: Inflammasomes damping down disorders of pregnancy. Hum. Reprod. Update 2014. [CrossRef] [PubMed]

8. Goodwin, G.H.; Sanders, C.; Johns, E.W. A new group of chromatin-associated proteins with a high content of acidic and basic amino acids. Eur. J. Biochem._FEBS 1973, 38, 14-19. [CrossRef]

9. Scaffidi, P.; Misteli, T.; Bianchi, M.E. Release of chromatin protein hmgb1 by necrotic cells triggers inflammation. Nature 2002, 418, 191-195. [CrossRef] [PubMed]

10. O'Connor, K.A.; Hansen, M.K.; Rachal Pugh, C.; Deak, M.M.; Biedenkapp, J.C.; Milligan, E.D.; Johnson, J.D.; Wang, H.; Maier, S.F.; Tracey, K.J.; et al. Further characterization of high mobility group box 1 (hmgb1) as a proinflammatory cytokine: Central nervous system effects. Cytokine 2003, 24, 254-265. [CrossRef] [PubMed]

11. Campana, L.; Bosurgi, L.; Rovere-Querini, P. Hmgb1: A two-headed signal regulating tumor progression and immunity. Curr. Opin. Immunol. 2008, 20, 518-523. [CrossRef] [PubMed]

12. Bianchi, M.E.; Manfredi, A.A. High-mobility group box 1 (hmgb1) protein the crossroads between innate and adaptive immunity. Immunol. Rev. 2007, 220, 35-46. [CrossRef] [PubMed] 
13. Hori, O.; Brett, J.; Slattery, T.; Cao, R.; Zhang, J.; Chen, J.X.; Nagashima, M.; Lundh, E.R.; Vijay, S.; Nitecki, D.; et al. The receptor for advanced glycation end products (rage) is a cellular binding site for amphoterin. Mediation of neurite outgrowth and co-expression of rage and amphoterin in the developing nervous system. J. Biol. Chem. 1995, 270, 25752-25761. [CrossRef] [PubMed]

14. Andersson, U.; Wang, H.; Palmblad, K.; Aveberger, A.C.; Bloom, O.; Erlandsson-Harris, H.; Janson, A.; Kokkola, R.; Zhang, M.; Yang, H.; et al. High mobility group 1 protein (hmg-1) stimulates proinflammatory cytokine synthesis in human monocytes. J. Exp. Med. 2000, 192, 565-570. [CrossRef] [PubMed]

15. Wang, H.; Bloom, O.; Zhang, M.; Vishnubhakat, J.M.; Ombrellino, M.; Che, J.; Frazier, A.; Yang, H.; Ivanova, S.; Borovikova, L.; et al. Hmg-1 as a late mediator of endotoxin lethality in mice. Science 1999, 285, 248-251. [CrossRef] [PubMed]

16. Liu, K.; Mori, S.; Takahashi, H.K.; Tomono, Y.; Wake, H.; Kanke, T.; Sato, Y.; Hiraga, N.; Adachi, N.; Yoshino, T.; et al. Anti-high mobility group box 1 monoclonal antibody ameliorates brain infarction induced by transient ischemia in rats. FASEB J. 2007, 21, 3904-3916. [CrossRef] [PubMed]

17. Hamada, T.; Torikai, M.; Kuwazuru, A.; Tanaka, M.; Horai, N.; Fukuda, T.; Yamada, S.; Nagayama, S.; Hashiguchi, K.; Sunahara, N.; et al. Extracellular high mobility group box chromosomal protein 1 is a coupling factor for hypoxia and inflammation in arthritis. Arthritis Rheumatol. 2008, 58, 2675-2685. [CrossRef] [PubMed]

18. Sawa, H.; Ueda, T.; Takeyama, Y.; Yasuda, T.; Shinzeki, M.; Nakajima, T.; Kuroda, Y. Blockade of high mobility group box-1 protein attenuates experimental severe acute pancreatitis. World J. Gastroenterol. 2006, 12, 7666-7670. [CrossRef] [PubMed]

19. Abraham, E.; Arcaroli, J.; Carmody, A.; Wang, H.; Tracey, K.J. Hmg-1 as a mediator of acute lung inflammation. J. Immunol. 2000, 165, 2950-2954. [CrossRef] [PubMed]

20. Holmlund, U.; Wahamaa, H.; Bachmayer, N.; Bremme, K.; Sverremark-Ekstrom, E.; Palmblad, K. The novel inflammatory cytokine high mobility group box protein $1(\mathrm{hmgb} 1)$ is expressed by human term placenta. Immunology 2007, 122, 430-437. [CrossRef] [PubMed]

21. Wang, B.; Koga, K.; Osuga, Y.; Hirata, T.; Saito, A.; Yoshino, O.; Hirota, Y.; Harada, M.; Takemura, Y.; Fujii, T.; et al. High mobility group box 1 (hmgb1) levels in the placenta and in serum in preeclampsia. Am. J. Reprod. Immunol. 2011, 66, 143-148. [CrossRef] [PubMed]

22. Cooke, C.L.; Brockelsby, J.C.; Baker, P.N.; Davidge, S.T. The receptor for advanced glycation end products (rage) is elevated in women with preeclampsia. Pregnancy Hypertens. 2003, 22, 173-184. [CrossRef] [PubMed]

23. Mutlu, I.; Mutlu, M.F.; Biri, A.; Bulut, B.; Erdem, M.; Erdem, A. Effects of anticoagulant therapy on pregnancy outcomes in patients with thrombophilia and previous poor obstetric history. Blood Coagul. Fibrinolysis 2014. [CrossRef] [PubMed]

24. Buyse, F.G.; Wormgoor, B.H.; Bernard, J.T.; Koudstaal, J. Anticoagulant therapy of patients with repeated placental infarction. Obstet. Gynecol. 1974, 43, 844-848. [PubMed]

25. Kingdom, J.C.; Drewlo, S. Is heparin a placental anticoagulant in high-risk pregnancies? Blood 2011, 118, 4780-4788. [CrossRef] [PubMed]

26. D'Souza, R.; Keating, S.; Walker, M.; Drewlo, S.; Kingdom, J. Unfractionated heparin and placental pathology in high-risk pregnancies: Secondary analysis of a pilot randomized controlled trial. Placenta 2014, 35, 816-823. [CrossRef] [PubMed]

27. Rey, E.; Garneau, P.; David, M.; Gauthier, R.; Leduc, L.; Michon, N.; Morin, F.; Demers, C.; Kahn, S.R.; Magee, L.A.; et al. Dalteparin for the prevention of recurrence of placental-mediated complications of pregnancy in women without thrombophilia: A pilot randomized controlled trial. J. Thromb. Haemost. 2009, 7, 58-64. [CrossRef] [PubMed]

28. Rodger, M.A.; Carrier, M.; Le Gal, G.; Martinelli, I.; Perna, A.; Rey, E.; de Vries, J.I.P.; Gris, J.-C.; Low-Molecular-Weight Heparin for Placenta-Mediated Pregnancy Complications Study Group. Meta-analysis of low-molecular-weight heparin to prevent recurrent placenta-mediated pregnancy complications. Blood 2014, 123, 822-828. [CrossRef] [PubMed]

29. Alvarenga, V., Jr.; Pacheco, R.G.; Esposito, C.C.; Buongusto, F.; Lima Castelo-Branco, M.T.; Madi, K.; Belmiro, C.R.; Goncalves Pavao, M.S.; Pereira de Souza, H.S.; Schanaider, A. Ascidian (chordate-tunicate) and mammalian heparin enemas attenuate experimental diversion colitis. Surgery 2014, 155, 217-227. [CrossRef] [PubMed] 
30. Babazada, H.; Yamashita, F.; Hashida, M. Suppression of experimental arthritis with self-assembling glycol-split heparin nanoparticles via inhibition of TLR4-NF-kB signaling. J. Control. Release 2014, 194, 295-300. [CrossRef] [PubMed]

31. Qian, Y.; Xie, H.; Tian, R.; Yu, K.; Wang, R. Efficacy of low molecular weight heparin in patients with acute exacerbation of chronic obstructive pulmonary disease receiving ventilatory support. COPD J. Chronic Obstruct. Pulm. Dis. 2014, 11, 171-176. [CrossRef] [PubMed]

32. Poli, M.; Asperti, M.; Ruzzenenti, P.; Mandelli, L.; Campostrini, N.; Martini, G.; Di Somma, M.; Maccarinelli, F.; Girelli, D.; Naggi, A.; et al. Oversulfated heparins with low anticoagulant activity are strong and fast inhibitors of hepcidin expression in vitro and in vivo. Biochem. Pharmacol. 2014, 92, 467-475. [CrossRef] [PubMed]

33. Liu, R.; Mori, S.; Wake, H.; Zhang, J.; Liu, K.; Izushi, Y.; Takahashi, H.K.; Peng, B.; Nishibori, M. Establishment of in vitro binding assay of high mobility group box-1 and s100a12 to receptor for advanced glycation endproducts: Heparin's effect on binding. Acta Med. Okayama 2009, 63, 203-211. [PubMed]

34. Ling, Y.; Yang, Z.Y.; Yin, T.; Li, L.; Yuan, W.W.; Wu, H.S.; Wang, C.Y. Heparin changes the conformation of high-mobility group protein 1 and decreases its affinity toward receptor for advanced glycation endproducts in vitro. Int. Immunopharmacol. 2011, 11, 187-193. [CrossRef] [PubMed]

35. Merenmies, J.; Pihlaskari, R.; Laitinen, J.; Wartiovaara, J.; Rauvala, H. 30-kda heparin-binding protein of brain (amphoterin) involved in neurite outgrowth. Amino acid sequence and localization in the filopodia of the advancing plasma membrane. J. Biol. Chem. 1991, 266, 16722-16729. [PubMed]

36. Parazzini, F.; Cortinovis, I.; Bortolus, R.; Fedele, L. Standards of birth weight in Italy. Ann. Ostet. Ginecol. Med. Perinat. 1991, 112, 203-246. [PubMed]

37. Bertino, E.; Di Battista, E.; Bossi, A.; Pagliano, M.; Fabris, C.; Aicardi, G.; Milani, S. Fetal growth velocity: Kinetic, clinical, and biological aspects. Arch. Dis. Child. Fetal Neonatal Ed. 1996, 74, F10-F15. [CrossRef] [PubMed]

38. Lappas, M.; Rice, G.E. The role and regulation of the nuclear factor kappa b signalling pathway in human labour. Placenta 2007, 28, 543-556. [CrossRef] [PubMed]

39. Cornelli, U.; Fareed, J. Human pharmacokinetics of low molecular weight heparins. Semin. Thromb. Hemost. 1999, 25 (Suppl. 3), 57-61. [PubMed]

40. Sobel, M.L.; Kingdom, J.; Drewlo, S. Angiogenic response of placental villi to heparin. Obstet. Gynecol. 2011, 117, 1375-1383. [CrossRef] [PubMed]

41. Drewlo, S.; Levytska, K.; Sobel, M.; Baczyk, D.; Lye, S.J.; Kingdom, J.C. Heparin promotes soluble vegf receptor expression in human placental villi to impair endothelial vegf signaling. J. Thromb. Haemost. 2011, 9, 2486-2497. [CrossRef] [PubMed]

42. Germanova, A.; Koucky, M.; Hajek, Z.; Parizek, A.; Zima, T.; Kalousova, M. Soluble receptor for advanced glycation end products in physiological and pathological pregnancy. Clin. Biochem. 2010, 43, 442-446. [CrossRef] [PubMed]

43. Pradervand, P.A.; Clerc, S.; Frantz, J.; Rotaru, C.; Bardy, D.; Waeber, B.; Liaudet, L.; Vial, Y.; Feihl, F. High mobility group box 1 protein (hmgb-1): A pathogenic role in preeclampsia? Placenta 2014, 35, 784-786. [CrossRef] [PubMed]

44. Chen, Q.; Yin, Y.X.; Wei, J.; Tong, M.; Shen, F.; Zhao, M.; Chamley, L. Increased expression of high mobility group box 1 (hmgb1) in the cytoplasm of placental syncytiotrophoblast from preeclamptic placentae. Cytokine 2016, 85, 30-36. [CrossRef] [PubMed]

45. Giacobbe, A.; Grasso, R.; Imbesi, G.; Salpietro, C.D.; Grasso, L.; Lagana, A.S.; Triolo, O.; Di Benedetto, A. High mobility group protein b1: A new biomarker of obesity in pregnant women? Gynecol. Endocrinol. 2015, 31, 113-115. [CrossRef] [PubMed]

46. Romero, R.; Miranda, J.; Chaiworapongsa, T.; Korzeniewski, S.J.; Chaemsaithong, P.; Gotsch, F.; Dong, Z.; Ahmed, A.I.; Yoon, B.H.; Hassan, S.S.; et al. Prevalence and clinical significance of sterile intra-amniotic inflammation in patients with preterm labor and intact membranes. Am. J. Reprod. Immunol. 2014, 72, 458-474. [CrossRef] [PubMed]

47. Jiang, R.; Cai, J.; Zhu, Z.; Chen, D.; Wang, J.; Wang, Q.; Teng, Y.; Huang, Y.; Tao, M.; Xia, A.; et al. Hypoxic trophoblast hmgb1 induces endothelial cell hyperpermeability via the trl-4/caveolin-1 pathway. J. Immunol. 2014, 193, 5000-5012. [CrossRef] [PubMed] 
48. Redman, C.W.; Sargent, I.L. Immunology of pre-eclampsia. Am. J. Reprod. Immunol. 2010, 63, 534-543. [CrossRef] [PubMed]

49. Redman, C.W.; Tannetta, D.S.; Dragovic, R.A.; Gardiner, C.; Southcombe, J.H.; Collett, G.P.; Sargent, I.L. Review: Does size matter? Placental debris and the pathophysiology of pre-eclampsia. Placenta 2012, 33 (Suppl.), S48-S54. [CrossRef] [PubMed]

50. Chekir, C.; Nakatsuka, M.; Noguchi, S.; Konishi, H.; Kamada, Y.; Sasaki, A.; Hao, L.; Hiramatsu, Y. Accumulation of advanced glycation end products in women with preeclampsia: Possible involvement of placental oxidative and nitrative stress. Placenta 2006, 27, 225-233. [CrossRef] [PubMed]

51. Bose, P.; Black, S.; Kadyrov, M.; Weissenborn, U.; Neuten, J.; Regan, L.; Huppertz, B. Heparin and aspirin attenuate placental apoptosis in vitro: Implications for early pregnancy failure. A. J. Obstet. Gynecol. 2005, 192, 23-30. [CrossRef] [PubMed]

52. D'Ippolito, S.; Di Nicuolo, F.; Marana, R.; Castellani, R.; Stinson, J.; Tersigni, C.; Scambia, G.; Di Simone, N. Emerging nonanticoagulant role of low molecular weight heparins on extravillous trophoblast functions and on heparin binding-epidermal growth factor and cystein-rich angiogenic inducer 61 expression. Fertil. Steril. 2012, 98, 1028-1036. [CrossRef] [PubMed]

53. Bierhaus, A.; Humpert, P.M.; Morcos, M.; Wendt, T.; Chavakis, T.; Arnold, B.; Stern, D.M.; Nawroth, P.P. Understanding rage, the receptor for advanced glycation end products. J. Mol. Med. (Berl.) 2005, 83, 876-886. [CrossRef] [PubMed]

54. Andersson, A.; Covacu, R.; Sunnemark, D.; Danilov, A.I.; Dal Bianco, A.; Khademi, M.; Wallstrom, E.; Lobell, A.; Brundin, L.; Lassmann, H.; et al. Pivotal advance: Hmgb1 expression in active lesions of human and experimental multiple sclerosis. J. Leukoc. Biol. 2008, 84, 1248-1255. [CrossRef] [PubMed]

55. Huebener, P.; Pradere, J.P.; Hernandez, C.; Gwak, G.Y.; Caviglia, J.M.; Mu, X.; Loike, J.D.; Jenkins, R.E.; Antoine, D.J.; Schwabe, R.F. The hmgb1/rage axis triggers neutrophil-mediated injury amplification following necrosis. J. Clin. Investig. 2015, 125, 539-550. [CrossRef] [PubMed]

56. Bredeson, S.; Papaconstantinou, J.; Deford, J.H.; Kechichian, T.; Syed, T.A.; Saade, G.R.; Menon, R. Hmgb1 promotes a 338 mapk associated non-infectious inflammatory response pathway in human fetal membranes. PLoS ONE 2014, 9, e113799. [CrossRef] [PubMed]

57. Park, J.S.; Gamboni-Robertson, F.; He, Q.; Svetkauskaite, D.; Kim, J.Y.; Strassheim, D.; Sohn, J.W.; Yamada, S.; Maruyama, I.; Banerjee, A.; et al. High mobility group box 1 protein interacts with multiple toll-like receptors. Am. J. Physiol. Cell Physiol. 2006, 290, C917-C924. [CrossRef] [PubMed]

58. Musumeci, D.; Roviello, G.N.; Montesarchio, D. An overview on hmgb1 inhibitors as potential therapeutic agents in hmgb1-related pathologies. Pharmacol. Ther. 2014, 141, 347-357. [CrossRef] [PubMed]

59. Sharma, L.; Wu, J.; Patel, V.; Sitapara, R.; Rao, N.V.; Kennedy, T.P.; Mantell, L.L. Partially-desulfated heparin improves survival in pseudomonas pneumonia by enhancing bacterial clearance and ameliorating lung injury. J. Immunotoxicol. 2014, 11, 260-267. [CrossRef] [PubMed]

60. Mitola, S.; Belleri, M.; Urbinati, C.; Coltrini, D.; Sparatore, B.; Pedrazzi, M.; Melloni, E.; Presta, M. Cutting edge: Extracellular high mobility group box-1 protein is a proangiogenic cytokine. J. Immunol. 2006, 176, 12-15. [CrossRef] [PubMed]

61. Schlueter, C.; Weber, H.; Meyer, B.; Rogalla, P.; Roser, K.; Hauke, S.; Bullerdiek, J. Angiogenetic signaling through hypoxia: Hmgb1: An angiogenetic switch molecule. Am. J. Pathol. 2005, 166, 1259-1263. [CrossRef]

62. Zhu, L.; Zhang, Z.; Zhang, L.; Shi, Y.; Qi, J.; Chang, A.; Gao, J.; Feng, Y.; Yang, X. Hmgb1-rage signaling pathway in severe preeclampsia. Placenta 2015, 36, 1148-1152. [CrossRef] [PubMed]

63. Kalinina, N.; Agrotis, A.; Antropova, Y.; DiVitto, G.; Kanellakis, P.; Kostolias, G.; Ilyinskaya, O.; Tararak, E.; Bobik, A. Increased expression of the DNA-binding cytokine hmgb1 in human atherosclerotic lesions: Role of activated macrophages and cytokines. Arterioscler. Thromb. Vasc. Biol. 2004, 24, 2320-2325. [CrossRef] [PubMed]

64. Wang, H.; Vishnubhakat, J.M.; Bloom, O.; Zhang, M.; Ombrellino, M.; Sama, A.; Tracey, K.J. Proinflammatory cytokines (tumor necrosis factor and interleukin 1) stimulate release of high mobility group protein-1 by pituicytes. Surgery 1999, 126, 389-392. [CrossRef]

65. Xiong, X.X.; Gu, L.J.; Shen, J.; Kang, X.H.; Zheng, Y.Y.; Yue, S.B.; Zhu, S.M. Probenecid protects against transient focal cerebral ischemic injury by inhibiting hmgb1 release and attenuating aqp4 expression in mice. Neurochem. Res. 2014, 39, 216-224. [CrossRef] [PubMed] 
66. Shen, M.; Lu, J.; Dai, W.; Wang, F.; Xu, L.; Chen, K.; He, L.; Cheng, P.; Zhang, Y.; Wang, C.; et al. Ethyl pyruvate ameliorates hepatic ischemia-reperfusion injury by inhibiting intrinsic pathway of apoptosis and autophagy. Mediat. Inflamm. 2013, 2013, 461536. [CrossRef] [PubMed]

67. Entezari, M.; Javdan, M.; Antoine, D.J.; Morrow, D.M.; Sitapara, R.A.; Patel, V.; Wang, M.; Sharma, L.; Gorasiya, S.; Zur, M.; et al. Inhibition of extracellular hmgb1 attenuates hyperoxia-induced inflammatory acute lung injury. Redox Biol. 2014, 2, 314-322. [CrossRef] [PubMed]

68. Raymond, D.; Peterson, E. A critical review of early-onset and late-onset preeclampsia. Obstet. Gynecol. Surv. 2011, 66, 497-506. [CrossRef] [PubMed]

69. Livak, K.J.; Schmittgen, T.D. Analysis of relative gene expression data using real-time quantitative pcr and the 2(-delta delta c(t)) method. Methods 2001, 25, 402-408. [CrossRef] [PubMed]

Sample Availability: Samples of the compounds are not available from the authors.

(C) 2017 by the authors. Licensee MDPI, Basel, Switzerland. This article is an open access article distributed under the terms and conditions of the Creative Commons Attribution (CC BY) license (http://creativecommons.org/licenses/by/4.0/). 